UDC 616-056.7-07

\title{
Molecular-genetic characterization of Ukrainian patients with mucopolysaccharidosis I: identification of three new mutations in $\alpha$-L-iduronidase gene
}

\author{
N. S. Trofimova ${ }^{1,2}$, N. V. Olkhovich ${ }^{1,2}$ \\ ${ }^{1}$ National Children's Specialized Hospital Okhmatdyt, Ministry of Health of Ukraine \\ 28/1, Chornovola Str., Kyiv, Ukraine, 01135 \\ 2 State Institute of Genetic and Regenerative Medicine, NAMS of Ukraine \\ 67, Vyshhorodska Str., Kyiv, Ukraine, 04114 \\ ntrofimofa@gmail.com
}

\begin{abstract}
Mucopolysaccharidosis I (MPS I) is a rare hereditary autosomal-recessive metabolic disorder,which occurs due to the deficiency of the lysosomal enzyme $\alpha$-L-iduronidase (IDUA; EC 3.2.1.76). There are three clinical forms of MPS I: Hurler syndrome, MPS I H; MIM \# 607014, ORPHA 93473, Hurler/Scheie syndrome, MPS I H/S; MIM \# 607015, ORPHA 93476, Scheie syndrome, MPS I S; MIM \# 607016, ORPHA 93474. Aim. To identify the spectrum of mutations in the IDUA gene in Ukrainian patients with MPS I. Methods. RFLPanalysis, automated sequencing. Results. We have identified $100 \%(34 / 34)$ mutant alleles of the IDUA gene among 18 Ukrainian patients (one proband had a sibling with the identical genotype) with MPS I from 17 families. The spectrum of mutations in the IDUA gene in Ukrainian patients with MPS I is represented by six known missence mutations: p.Q70*,p.W402*,p.A75T, p.A327P, p.P533L, p.S633I; two deletions: c.1398delC and c.46_57del_12, one insertion: c.889_899_ins_12, and one mutation in the splicing zone IVS11ds+5G-A. Three new missence mutations were revealed by us in the IDUA gene: p.N372S, p.Q563P and p. S633*. Conclusions. Our results may be used for planning the most reasonable algorithm of the moleculargenetic analysis of Ukrainian patients with MPS I.
\end{abstract}

Ke yw or d s: mucopolysaccharidosis, Hurler syndrome, Scheie syndrome, $\alpha$-L-iduronidase.

\section{Introduction}

Mucopolysaccharidosis I (MPS I) is a rare hereditary autosomal-recessive metabolic disorder, which occurs due to the deficiency of the lysosomal enzyme $\alpha$-L-iduronidase (IDUA; EC 3.2.1.76), involved in the multistage catabolism of dermatan sulphate (DS) and heparan sulphate (HS). The deficiency in $\alpha$-L-iduronidase leads to the accumulation of non-degraded GAG substrate in the lysosomes of cells of different organs and tissues $[1,2]$.

Although the clinical phenotype of MPS I is a continuous spectrum from severe forms to mild ones, generally three clinical forms are distinguished: 1) severe form (Hurler syndrome, MPS I H; MIM \# 607014, ORPHA 93473), with the manifestation of symptoms by the age of 12 months, life span of no more than 10 years and mental retardation, which is manifested at the age under three; 2) intermediate form (Hurler-Scheie syndrome, MPS I H/S; MIM \# 607015, ORPHA 93476), with the manifestation of symptoms at the age from 1 to 6 years, longer life span and no or mild mental retardation, which is never manifested under 3; 3) mild form (Scheie syndrome, MPS I S; MIM \# 607016, ORPHA 93474), with the manifestation of the first symptoms of the disease af-

(C) 2016 N. S. Trofimova et al.; Published by the Institute of Molecular Biology and Genetics, NAS of Ukraine on behalf of Biopolymers and Cell. This is an Open Access article distributed under the terms of the Creative Commons Attribution License (http://creativecommons.org/licenses/by/4.0/), which permits unrestricted reuse, distribution, and reproduction in any medium, provided the original work is properly cited 
ter the age of 5, unchanged life span and complete absence of mental retardation [1].

The gene, encoding $\alpha$-L-iduronidase (IDUA; MIM \# 252800), was mapped in locus 4p16.3; it consists of 14 exons, separated by 13 introns. An open reading frame of cDNA $(\mathrm{ORF})$ is $\sim 2$ kilobases long and encodes the polypeptide of 653 amino acids [3]. At present there are over 220 mutations, identified and characterized in the IDUA gene, including missence/nonsense mutations, small deletions and insertions, four gross-deletions, one grossinsertion, 36 splicing mutations and three complex mutations (Human Gene Mutation DatabaseHGMD, http://www.hgmd.cf.ac.uk/ac/index.php). In general most mutations occur less than in $3 \%$ of cases or are single.

The missence mutations p.W402*,p.Q70*,p.P533R and p.G51D are the most common for the gene IDUA. Mutation p.W402* has about $50 \%$ distribution frequency in Northern Europe, Great Britain, North America, and Spain, whereas its frequency in the Russian Federation, Italy, and Brazil is $4 \%, 11 \%$, and $20 \%$ respectively, according to the estimates of different researchers $[4,5]$. On the contrary, mutation p.Q70* occurs in Scandinavia and the Russian Federation much more frequently (up to $50 \%$ ) than in other countries [6]. The missence mutation p.P533R of probable NorthAfrican origin is wide-spread in the Mediterranean region, and has $13 \%$ and $10 \%$ of mutant alleles in the IDUA gene in Italy and Spain, respectively. According to the data of Italian researchers, the missence mutation p.G51D is major for Italy only, and is registered with the frequency of $13 \%$ for mutant alleles in the IDUA gene among Italian patients with mucopolysaccharidosis I [4]. The frequency of mutations in the IDUA gene for Ukraine has not been defined yet.

The aim of our work was to identify the whole spectrum of mutations in the IDUA gene in Ukrainian patients with MPS I.

\section{Materials and Methods}

The material of the research was the blood of 17 patients with MPS I ( 7 boys and 10 girls), whose diagnosis was confirmed in the Clinical Genetics
Laboratory, NCSH OKHMATDYT of the Ministry of Health of Ukraine, using biochemical methods with the determination of the activity of $\alpha$-L-iduronidase enzyme in lysosomes, and the blood of their 37 relatives (siblings and parents) from different regions of Ukraine [7]. The age of the patients at the moment of the diagnosis determination was $2 \pm 1$ years for Hurler syndrome, $14 \pm 1$ years for Hurler-Scheie syndrome and Scheie syndrome. One proband had a sibling with the identical genotype, who was not taken into consideration while identifying the mutation frequency. For control of the pathogenicity of new mutations, the blood samples of 100 volunteers aged 18 to 60 years without any clinical signs of lysosomal pathology were used. The parents of all the patients and volunteers gave their informed consent for the studies. The bioethics committee approved the research.

DNAs were extracted from the whole blood using the commercial NeoSorb kits (Neogen, Ukraine). The identification of major mutations p.Q70* and p.W402* was conducted using the RFLP-analysis as described in our previous publication [7].

The identification of rare mutations in the IDUA gene involved the method of direct automated sequencing by the Sanger's method using ABI 3130 analyzer (Applied Biosystems) according to the manufacturer's protocol. The sequences of primers for each of fourteen exons of the IDUA gene were selected using Primer3 program (http://simgene. com/Primer3). The analysis of sequencing results was made using programs Sequencing Analysis, v.1.1/3.1 (Applied Biosystems, Life Technologies Corporation, USA), Chromas and Blast (http://www. ncbi.nlm.nih.gov/blast). The analysis of pathogenicity of new mutations was made using programs PolyPhen2 and Provean (http://genetics.bwh.harvard.edu/pph2/, http://provean.jcvi.org/index.php).

\section{Results and Discussion}

The studies, conducted by us, allowed identifying $100 \%(34 / 34)$ mutant alleles of the IDUA gene in Ukrainian patients with MPS I (Table 1).

The most common mutation for the investigated Ukrainian patients with MPS I was nonsense -muta- 
Table 1. The localization of the identified mutations in exons of the IDUA gene and their frequency

\begin{tabular}{|c|c|c|c|c|}
\hline $\begin{array}{l}\text { Nucleotide replacement } \\
\text { in the IDUA gene }\end{array}$ & $\begin{array}{l}\text { Aminoacid replacement in the } \\
\text { molecule of } \alpha \text {-L-iduronidase }\end{array}$ & $\begin{array}{l}\text { Number } \\
\text { of exons }\end{array}$ & $\begin{array}{l}\text { Number of mutant alleles } \\
\text { in the ratio to the general } \\
\text { number of alleles }\end{array}$ & $\begin{array}{l}\text { Reference to the first description of } \\
\text { the mutation in the IDUA gene }\end{array}$ \\
\hline c.46_57del_12 & p.S16_A19del & 1 & $1 / 34$ & Bunge et al., 1994, [8] \\
\hline c. $208 \mathrm{C}>\mathrm{T}$ & p.Q70* & 2 & $11 / 34$ & Clarke et al., 1993, [9] \\
\hline c. $223 \mathrm{G}>\mathrm{A}$ & p.A75T & 2 & $1 / 34$ & Clarke et al., 1994, [10] \\
\hline c.889_899_ins_12 & p.T296_T299dup & 7 & $3 / 34$ & Bunge et al., 1995, [11] \\
\hline c. $979 \mathrm{G}>\mathrm{C}$ & p.A327P & 8 & $1 / 34$ & Bunge et al., 1995, [11] \\
\hline c. $1115 \mathrm{~A}>\mathrm{G}$ & p.N372S & 8 & $3 / 34$ & Our studies \\
\hline c. $1205 \mathrm{G}>\mathrm{A}$ & p.W402* & 9 & $5 / 34$ & Scott et al., 1992, [12] \\
\hline c. $1398 \mathrm{delC}$ & p.P467Rfs*58 & 9 & $3 / 34$ & Bertola et al., 2011, [4] \\
\hline c. $1598 \mathrm{C}>\mathrm{T}$ & p.P533L & 11 & $1 / 34$ & Voskoboeva et al., 1998, [13] \\
\hline IVS11ds $+5 \mathrm{G}-\mathrm{A}$ & $1738+5 \mathrm{G}>\mathrm{A}$ & Int.11 & $1 / 34$ & Verturi et al., 2002, [14] \\
\hline c. $1688 \mathrm{~A}>\mathrm{C}$ & p.Q563P & 12 & $1 / 34$ & Our studies \\
\hline c. $1898 \mathrm{C}>\mathrm{T}$ & p.S633I & 14 & $1 / 34$ & Beesley et al., 2001, [15] \\
\hline c. $1898 \mathrm{C}>\mathrm{A}$ & p.S633* & 14 & $2 / 34$ & Our studies \\
\hline
\end{tabular}

tion p.Q70* - 11 alleles out of 34 . The frequency of this mutation is $32.4 \%(11 / 34)$ which is close to the indices of the distribution of this mutation in Europe [6]. Two patients had this mutation in the homozygous state, seven patients - in the heterozygous state.

The other major mutation p.W402* in the IDUA gene was found in five patients with MPS I in the heterozygous state, which is $14.7 \%(5 / 34)$, i.e. its distribution in Ukraine is close to the indices of Italy [4]. Two compound heterozygotes p.Q70*/p. W402* were revealed.

In addition to major mutations, the previously described deletion c.1398delC was identified with high frequency of $8.8 \%(3 / 34)$ in Ukraine, in homo- and heterozygous state in the patients with MPS I.

Four previously revealed mutations were described among the missence mutations, identified during the analysis, in addition to major p.Q70* and p.W402*: in exon 2 - p.A75T, in exon 8 - p.A327P, in exon $11-$ p.P533L, and in exon $14-$ p.S633I. The previously described mutation in the splicing zone for exon 11 IVS11ds $+5 \mathrm{G}-\mathrm{A}$ was identified for one patient in one allele. A previously known insertion of 12 basic pairs c.889_899_ins_12 was revealed in exon 7 in four patients, two of them were siblings. A previously described deletion of $12 \mathrm{bp}$ in exon 1 c.46_57del_12 was found in one patient.

Additionally, three mutations in the IDUA gene, which have been neither previously described nor included into HGMD database, were identified by us, namely, three missence mutations: p.N372S in exon 8 (in three alleles in two patients), p.Q563P in exon 12 (in one allele), and nonsense-mutation p.S633* in exon 14 (in two alleles in one patient) (Fig. 1).

No changes in the sequence of nucleotides of the IDUA gene were identified by us in the individuals of the control group, i.e. they may be estimated as mutations, and not as a polymorphic variant.

The detailed analysis of these mutations using programs PolyPhen2 and Provean confirmed their pathological character (Fig. 2).

A new missence mutation p.N372S, which was identified in exon 8, leads to the replacement of asparagine for serine, due to which the length of protein does not change, but there is a disorder in the functioning of the protein, which causes the change in the splicing site. A new missence mutation $p$. Q563P, which was identified in exon 12, results in the replacement of glutamine for proline, which does not have any significant impact on the protein func- 

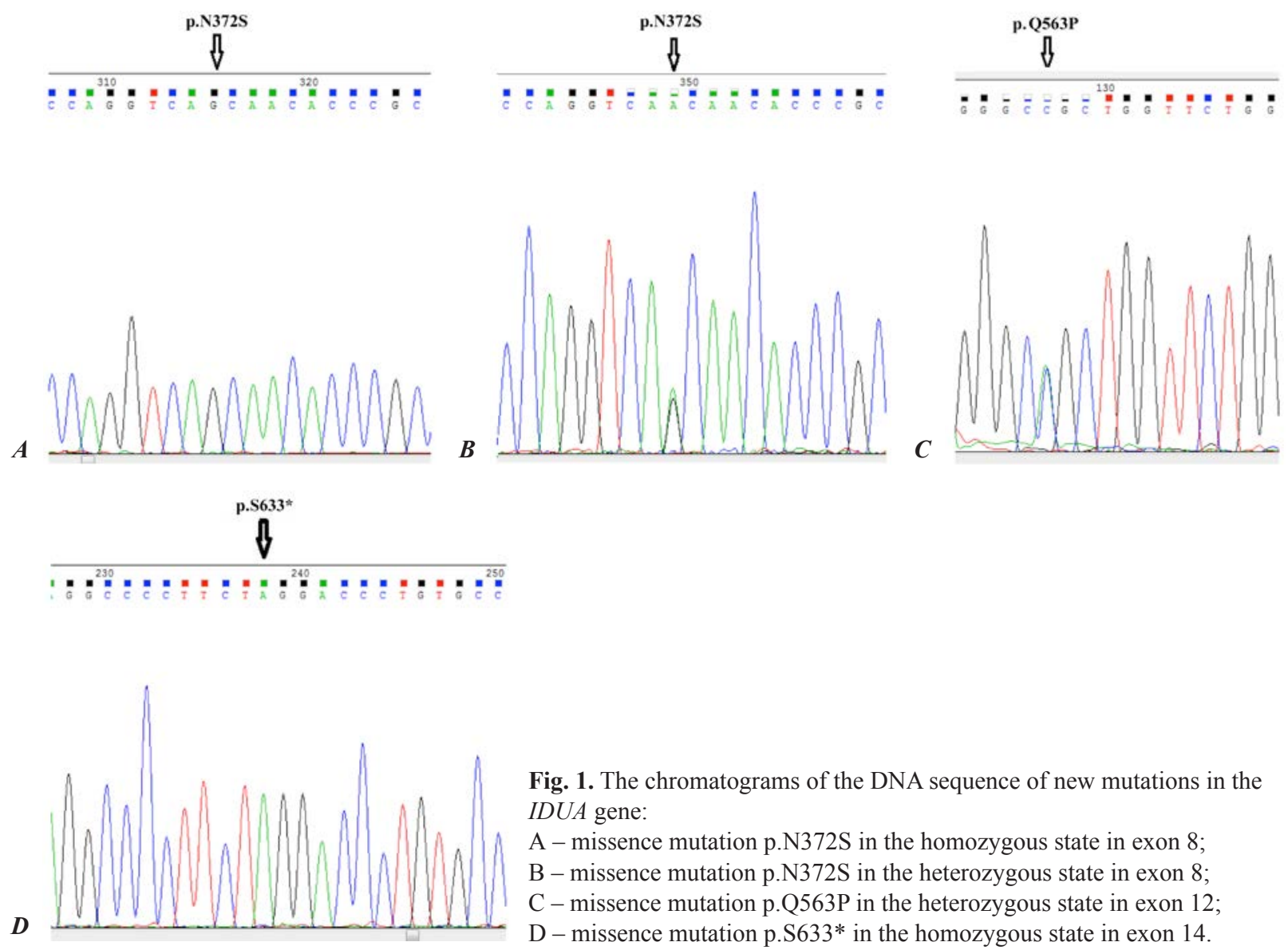

Fig. 1. The chromatograms of the DNA sequence of new mutations in the IDUA gene:

A - missence mutation p.N372S in the homozygous state in exon 8;

$\mathrm{B}-$ missence mutation p.N372S in the heterozygous state in exon 8;

C - missence mutation p.Q563P in the heterozygous state in exon 12;

$\mathrm{D}-$ missence mutation p.S633* in the homozygous state in exon 14.

$\begin{array}{ll}\text { species } \\ \text { Human } \\ \text { mutated } \\ \text { Fcatus } \\ \text { Mmusculus } \\ \text { Ggallus } \\ \text { Drerio } \\ \text { Dmelanogaster } \\ \text { A } & \text { Xtropicalis } \\ & \text { Species } \\ & \text { Human } \\ & \text { mutated } \\ & \text { Mmusculus } \\ & \text { Ggallus } \\ & \text { Drerio } \\ & \text { Dmelanogaster } \\ \text { B } & \text { Xtropicalis }\end{array}$

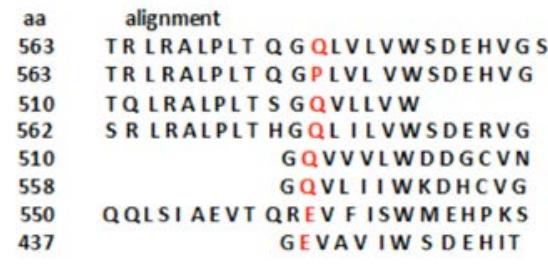

Fig. 2. The conservatism of new missence mutations in our studies:

A - new mutation p.Q563P (c.1688A >C);

$\mathrm{B}$ - new mutation p.N372S (c.1115A>G). tion, leading only to the point replacement of the aminoacid in its structure. A new nonsense-mutation p.S633* in exon 14 forms a stop-codon and shortens the protein by 21 aminoacids $(\sim 10 \%$ from the total length of the protein).

Therefore, the spectrum of mutations in the IDUA gene in Ukrainian patients with MPS I at presen is represented by 9 missence mutations, 2 deletions of 1 and $12 \mathrm{bp}, 1$ insertion of $12 \mathrm{bp}$, and 1 mutation in the splicing zone (Fig. 3).

Similar to many other European populations, two mutations may be considered to be major for Ukrainian patients with MPS I: p.Q70* (32.35\%) and $\mathrm{p} . \mathrm{W} 402 *(14.7 \%)$. As for rare mutations, the most common ones were found to be deletion c.1398delC $(8.8 \%)$ and a new missence mutation p.N372S (8.8\%), which were revealed in the homo- 


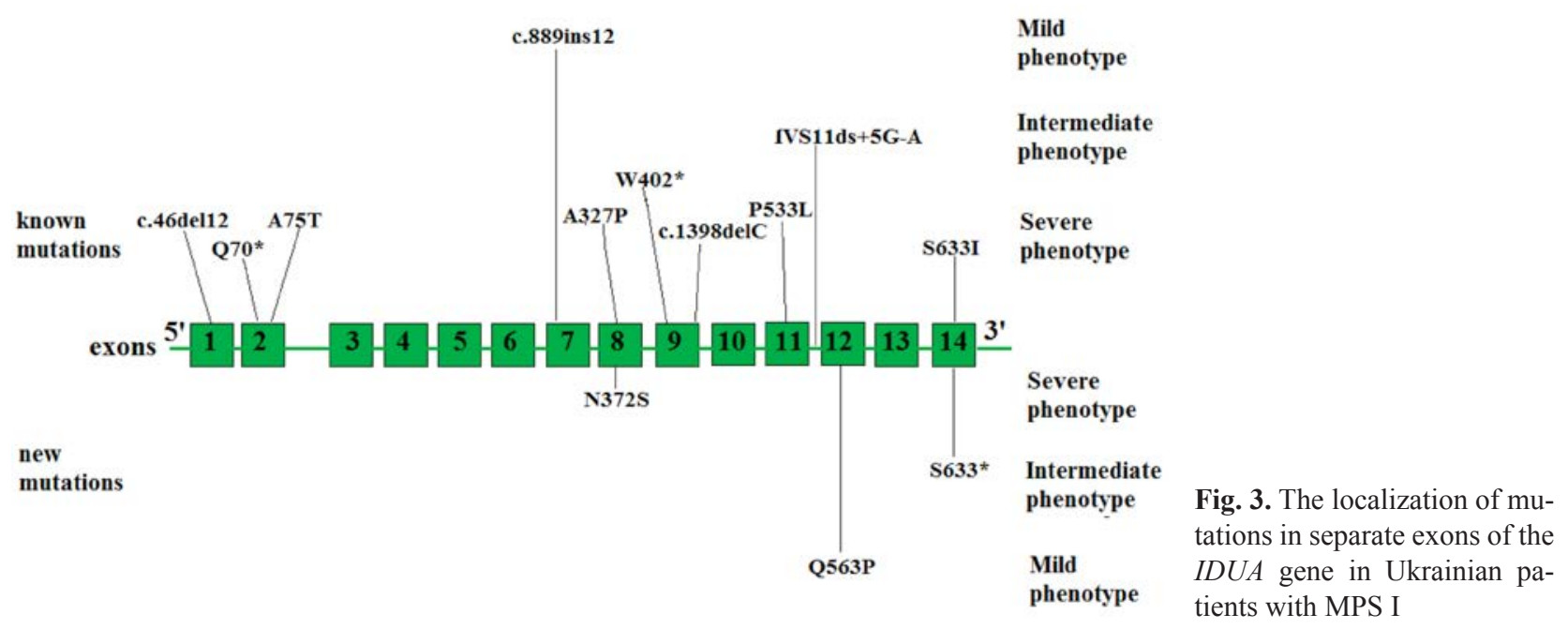

and heterozygous state among Ukrainian patients with MPS I. The insertion c.889 899 ins 12 $(8.8 \%)$, identified in four patients in the heterozygous state, two of whom were siblings, was also found to be quite common. A new nonsense mutation p.S633* (5.9\%), which was identified in one patient, may also potentially be more common for Ukraine, as it was identified in the homozygous state. However, this may also be a result of the intrafamilial accumulation of the pathological mutation after the marriage of close relatives, who are parents of this patient. Other mutations were represented by single cases. Probably, these frequencies may change with further identification of new patients. The most rare mutations, identified by us in Ukrainian patients with MPS I, were localized in exons 2, 7, 8, 9, and 14 , and one in each - in exons 1,11 , and 12 of the IDUA gene.

The complete characterization of the patients with MPS I with the consideration of the clinical form of the disease is presented in Table 2.

The results of molecular-genetic analysis of Ukrainian patients with MPS I, obtained by us, demonstrated that all the patients with major mutation p.Q70* in the homozygous state, and two patients, who were found to be compound heterozygotes of p.Q70X*/ p.W402*, have a severe form of the disease - Hurler syndrome, which is in good agreement with the data of other researchers about the associa- tion of major nonsense -mutations p.Q70* and p.W402* with the severe disease progression $[6,8]$. The severe progression of MPS I was also noted for patients with the major mutation $\mathrm{p} . \mathrm{W} 402 *$ in one allele and the missence mutation p.A75T (1 person) [15]. A previously known single-nucleotide deletion c.1398delC, identified in two patients in both the homozygous state and the compound with the major mutation p.W402*, also characterized the presence of the severe clinical form of MPS I, Hurler syndrome, in patients [4].

Two patients, who had a new, previously not described missence mutation p.N372S in the homozygous state and in the compound with the major mutation $\mathrm{p}$. Q70*, were characterized by early onset of the disease and a severe phenotype. Three patients with the compounds combination of major mutations and rare mutations (genotypes p.Q70*/p.P533L, p.Q70*/c.46_57 del_12 and p.W402*/p.S633I) had a severe form of the disease - Hurler syndrome with early onset of the disease.

Hurler-Scheie syndrome, which was identified in two patients, was associated with genotypes IVS11ds $+5 \mathrm{G}-\mathrm{A} / \mathrm{c} .889899$ ins 12 and a new mutation in the homozygous state p.S633*/p.S633*.

Scheie syndrome was diagnosed in four patients, two of whom were siblings, with genotypes c.889_899_ins_12/p.Q70* - in three patients, and the missence mutation p.A327P in the 
Table 2. The characterization of patients with MPS I

\begin{tabular}{|c|c|c|c|c|c|}
\hline$\#$ & Gender & $\begin{array}{c}\text { Age at the moment of diagnosis } \\
\text { determination }\end{array}$ & Phenotype & First allele & Second allele \\
\hline 1 & $\mathrm{~F}$ & 1.5 y.o. & $\mathrm{H}$ & p.Q70* & p.Q70* \\
\hline 2 & M & 3.5 у.о. & $\mathrm{H}$ & p.Q70* & p.Q70* \\
\hline 3 & $\mathrm{~F}$ & 1 у.о. & $\mathrm{H}$ & p.Q70* & p.P533L \\
\hline 4 & M & 2.5 у.о. & $\mathrm{H}$ & p.Q70* & c.46_57_del_12 \\
\hline 5 & $\mathrm{~F}$ & 3 y.o. & $\mathrm{H}$ & p.Q70* & p.N372S \\
\hline 6 & M & 2.5 y.o. & $\mathrm{H}$ & p.Q70* & p.W402* \\
\hline 7 & $\mathrm{~F}$ & 3 y.o. & $\mathrm{H}$ & p.Q70* & p.W402* \\
\hline 8 & M & 2 у.о. & $\mathrm{H}$ & p.S633I & p.W402* \\
\hline 9 & $\mathrm{~F}$ & 2 y.o. & $\mathrm{H}$ & p.A75T & p.W402* \\
\hline 10 & $\mathrm{~F}$ & 4.5 y.o. & $\mathrm{H}$ & c. $1398 \mathrm{delC}$ & p.W402* \\
\hline 11 & $\mathrm{~F}$ & 2 у.о. & $\mathrm{H}$ & c. $1398 \mathrm{delC}$ & c.1398delC \\
\hline 12 & $\mathrm{~F}$ & 4 у.о. & $\mathrm{H}$ & p.N372S & p.N372S \\
\hline 13 & $\mathrm{~F}$ & 14 y.o. & $\mathrm{H} / \mathrm{S}$ & p.S633* & p.S633* \\
\hline 14 & M & 15 у.о. & $\mathrm{H} / \mathrm{S}$ & IVS11ds+5G-A & c.889_899_ins_12 \\
\hline 15 & M & 9 y.o. & $\mathrm{S}$ & p.Q70* & c.889_899_ins_12 \\
\hline 16 & M & 14 y.o. & $\mathrm{S}$ & p.Q70* & c.889_899_ins_12 \\
\hline 17 & $\mathrm{~F}$ & 8 y.o. & $\mathrm{S}$ & p.A327P & p.Q563P \\
\hline
\end{tabular}

$\mathrm{H}$ - Hurler syndrome, H/S - Hurler-Scheie syndrome, S - Scheie syndrome;

F - girls, M - boys;

Mutations highlighted in bold are new mutations, which have not been described in the literature.

compound with the new mutation p.Q563P - in one patient.

Therefore, our analysis of the molecular-genetic characterization of Ukrainian patients with MPS I allowed identifying $100 \%$ mutant alleles. High frequency of mutations p.Q70* (32.35\%) and p.W402* $(14.7 \%)$ among Ukrainian patients substantiates RFLP-screening for the presence of these mutations at the first stage of the molecular-genetic analysis. It would be reasonable to start the analysis during the identification of rare mutations, which have led to the development of the disease in the proband, with "hot" regions of the IDUA gene - exons 2, 7, 8, 9, and 14 , where most pathogenic mutations were localized in the patients, studied by us. During the planning of the analysis, this order would allow optimizing time and resources for the analysis and ensuring the maximal efficiency of the molecular genetic diagnostics of MPS I in Ukraine.

\section{Conclusions}

The molecular genetic analysis of pathogenic mutations in the IDUA gene in 18 Ukrainian patients with MPS I from 17 families (34 alleles) revealed $100 \%$ mutant alleles.

The share of the alleles with the major mutation p.Q70* was the largest $-32.35 \%$ (11/34). The other major mutation for European populations, p.W402*, was found in five patients $(14.7 \%)$ in one allele, so it is also major for Ukraine.

Most rare mutations, identified by us in Ukrainian patients with MPS I, were localized in exons 2, 7, 8, 9 , and 14 of the IDUA gene, and one in each - in exons 1,11 , and 12 .

Three previously not described missence mutations in the IDUA gene - p.N372S, p.Q563P and p.S633* - were also revealed.

The data of the conducted molecular genetic analysis of mutations in the IDUA gene may be used 
while planning the most reasonable algorithm of the molecular genetic analysis of Ukrainian patients with MPS I in order to enhance the quality of providing medical care to the families, suffering from this disease.

\section{Acknowledgments}

We are grateful to the clinical doctors of the Center of Orphan Diseases and the Medical Genetics Center of the National Children's Specialized Hospital Okhmatdyt for their providing clinical profiles of patients.

\section{REFERENCES}

1. Mehta A, Winchester B. Lysosomal storage disorders: a practical guide. London: Wiley-Blackwell, 2012;94-100.

2. Clarke LA (Updated [September 21, 2007]). Mucopolysaccharidosis Type I. In: GeneReviews at GeneTests: Medical Genetics Information Resource (database online). Copyright, University of Washington, Seattle. 1993-2007.

3. Scott HS, Guo XH, Hopwood JJ, Morris CP. Structure and sequence of the human alpha-L-iduronidase gene. Genomics. 1992;13(4):1311-3.

4. Bertola F, Filocamo M, Casati G, Mort M, Rosano C, TylkiSzymanska A, Tüysüz B, Gabrielli O, Grossi S, Scarpa M, Parenti G, Antuzzi D, Dalmau J, Di Rocco M, Dionisi Vici C, Okur I, Rosell J, Rovelli A, Furlan F, Rigoldi M, Biondi A, Cooper DN, Parini R. IDUA mutational profiling of a cohort of 102 European patients with mucopolysaccharidosis type I: identification and characterization of 35 novel $\alpha$-L-iduronidase (IDUA) alleles. Hum Mutat. 2011; 32(6):E2189-210.

5. Wang X, Zhang W, Shi H, Qiu Z, Meng Y, Yao F, Wei M. Mucopolysaccharidosis I mutations in Chinese patients: identification of 27 novel mutations and 6 cases involving prenatal diagnosis. Clin Genet. 2012;81(5):443-52.

6. Chistiakov DA, Savost'anov KV, Kuzenkova LM, Gevorkyan AK, Pushkov AA, Nikitin AG, Pakhomov AV, Vashakmadze ND, Zhurkova NV, Podkletnova TV, Mayansky NA, Namazova-Baranova LS, Baranov AA. Molecular characteristics of patients with glycosaminoglycan storage disorders in Russia. Clin Chim Acta. 2014;436:112-20.

7. Trofimova NS, Olkhovich NV, Gorovenko NG. Optimization of biochemical and molecular genetic diagnostics of I type mucopolysaccharidoses in Ukraine. Achievements of Biology and Medicine. 2014; 1(23):61-5.

8. Bunge S, Kleijer WJ, Steglich C, Beck M, Zuther C, Morris CP, Schwinger E, Hopwood JJ, Scott HS, Gal A. Mucopolysaccharidosis type I: identification of 8 novel mutations and determination of the frequency of the two common alpha-L-iduronidase mutations (W402X and Q70X) among European patients. Hum Mol Genet. 1994;3(6):861-6.

9. Clarke LA, Scott HS. Two novel mutations causing mucopolysaccharidosis type I detected by single strand conformational analysis of the alpha-L-iduronidase gene. Hum Mol Genet. 1993;2(8):1311-2.

10. Clarke LA, Nelson PV, Warrington CL, Morris CP, Hopwood JJ, Scott HS. Mutation analysis of 19 North American mucopolysaccharidosis type I patients: identification of two additional frequent mutations. Hum Mutat. 1994;3(3):275-82.

11. Bunge S, Kleijer WJ, Steglich C, Beck M, Schwinger E, Gal A. Mucopolysaccharidosis type I: identification of 13 novel mutations of the alpha-L-iduronidase gene. Hum $\mathrm{Mu}$ tat. 1995;6(1):91-4.

12. Scott HS, Litjens T, Hopwood JJ, Morris CP. A common mutation for mucopolysaccharidosis type I associated with a severe Hurler syndrome phenotype. Hum Mutat. 1992;1(2):103-8.

13. Voskoboeva EY, Krasnopolskaya XD, Mirenburg TV, Weber B, Hopwood JJ. Molecular genetics of mucopolysaccharidosis type I: mutation analysis among the patients of the former Soviet Union. Mol Genet Metab. 1998;65(2):174-80.

14. Venturi $N$, Rovelli A, Parini R, Menni F, Brambillasca $F$, Bertagnolio F, Uziel G, Gatti R, Filocamo M, Donati MA, Biondi A, Goldwurm S. Molecular analysis of 30 mucopolysaccharidosis type I patients: evaluation of the mutational spectrum in Italian population and identification of 13 novel mutations. Hum Mutat. 2002;20(3):231.

15. Beesley CE, Meaney CA, Greenland G, Adams V, Vellodi A, Young EP, Winchester BG. Mutational analysis of 85 mucopolysaccharidosis type I families: frequency of known mutations, identification of 17 novel mutations and in vitro expression of missense mutations. Hum Genet. 2001;109(5): 503-11.

\section{Молекулярно-генетична характеристика паціснтів 3 мукополісахаридозом I типу з України: виявлення трьох нових мутацій в гені $\alpha$-L-iдуронідази}

\section{Н. С. Трофімова, Н. В. Ольхович}

Мукополісахаридоз I типу (МПС I) - рідкісне спадкове аутосомно-рецесивне метаболічне захворювання, яке виникає внаслідок дефекту лізосомального ферменту $\alpha$-L-ідуронідази (IDUA; EC 3.2.1.76). Розрізняють 3 клінічних форми МПC I: синдром Гурлера, МПС I Г; МIM \# 607014, ORPHA 93473, синдром Гурлер/Шейе, МПС I Г/Ш; МIM \# 607015, ORPHA 93476 , синдром Шейе, МПС I Ш; MIM \# 607016, ORPHA 93474. Мета. Виявлення повного спектру мутацій в гені IDUA у пацієнтів з МПС І з України. Методи. ПДРФ-аналіз, метод прямого автоматичного секвенування по Сенгеру на аналізаторі АBI 3130 (Applied Biosystems). Результати. На підставі проведених нами досліджень було ідентифіковано 100\% (34/34) му- 
тантних алелів гену IDUA серед 18 хворих (один пробанд мав сибса с ідентичним генотипом) на МПС І пацієнтів з 17 родин 3 України. Спектр мутацій в гені IDUA у пацієнтів з МПC I в Україні представлений 6 відомими місенс-мутаціями - p.Q70*, p.W402*, p.A75T, p.A327P, p.P533L, p.S633I; 2 делеціями c.1398delC та с.46_57del_12, 1 інсерцією с.889_899_ins_12, та 1 мутацією в зоні сплайсінгу IVS11ds+5G-A. Нами було виявлено три нових місенс-мутації в гені IDUA: p.N372S, p.Q563P та p.S633*. Висновки. Дані проведеного молекулярно-генетичного аналізу мутацій в гені IDUA можуть бути використані при плануванні найбільш раціонального алгоритму молекулярно-генетичного аналізу пацієнтів з МПС І в Україні.

Кл юч ов і слов а: мукополісахаридоз, синдром Гурлер, синдром Шейе, $\alpha$-L-ідуронідаза.

\section{Молекулярно-генетическая характеристика пациентов с мукополисахаридозом I типа из Украины: виявление трёх новых мутаций в гене $\alpha$-L-идуронидазы}

\section{Н. С. Трофимова, Н. В. Ольхович}

Мукополисахаридоз I типа (МПС I) - редкое наследственное аутосомно-рецессивное метаболическое заболевание, которое возникает вследствие дефекта фермента $\alpha$-L-идуронидазы (IDUA; EC 3.2.1.76). Разделяют 3 клинических формы МПC I: синдром Гурлера, МПС I Г; МIM \# 607014, ORPHА 93473, син- дром Гурлер/Шейе, МПС I Г/Ш; MIM \# 607015, ORPHA 93476 , синдром Шейе, МПС I Ш; MIM \# 607016, ORPHA 93474. Цель. Выявление полного спектра мутаций в гене IDUA у пациентов с МПС I из Украины. Методы. ПДРФ-анализ, метод прямого автоматического секвенирования по Сенгеру на анализаторе ABI 3130 (Applied Biosystems). Результаты. На основании проведенных нами исследований было идентифицировано 100\% (34/34) мутантных аллелей гена IDUA среди 18 пациентов (два пробанда имели сибсов с идентичными генотипами) с МПС I из 17 семей из Украины. Спектр мутаций в гене $I D U A$ у пациентов с МПС I в Украине представлен известными 6 миссенс-мутациями - p.Q70*, p.W402*, p.A75T, p.A327P, p. P533L, p.S633I, 2 делециями - c.1398delC и c.46_57del_12, 1 инсерцией - c.889_899_ins_12 и 1 мутацией в зоне сплайсинга IVS11ds+5G-A. Нами было найдено три новых миссенс-мутаций в гене IDUA: p.N372S, p.Q563P и p.S633*. Выводы. Данные проведенного молекулярно-генетического анализа мутаций в гене IDUA могут быть использованы при планировании наиболее рационального алгоритма молекулярно-генетического анализа пациентов с МПС І в Украине.

К л юч е в ы е с л о в а: мукополисахаридоз, синдром Гурлер, синдром Шейе, $\alpha$-L-идуронидаза.

Received 10.10.2016 